Vol. 3, No. 1, 2020

D. P. Kindzera, R. R. Hosovskyi, Z. Ya. Hnativ, V. M. Atamanyuk

Lviv Polytechnic National University

Department of Chemical Engineering

kindzera74@ukr.net

\title{
EFFECTIVE TECHNIQUES FOR BIO-COAL BRIQUETTES PRODUCTION
}

https://doi.org/

The production of bio-coal briquettes gives an opportunity to utilize low grade coal as well as the great amount of agricultural residues, to increase the calorific value of obtained briquettes and to improve their chemical and physical properties. The present study is focused on developing the technological scheme which gives an opportunity to reduce the energy consumption in production line of composite fuel as well as to produce bio-coal briquettes with good mechanical integrity. The effect of the fixed bed length on the kinetic during the filtration drying of coal and sunflower biomass has been examined. Optimal parameters for the process implementation were identified for sunflower biomass: temperature of the heat agent $353 \mathrm{~K}$, velocity of the heat agent $1,66 \mathrm{~m} / \mathrm{s}$, length of the fixed bed $120 \cdot 10^{-3} \mathrm{~m}$ and for the coal: temperature of the heat agent $318 \mathrm{~K}$; pressure drop $5886 \mathrm{~Pa}$, length of the fixed bed $75.10^{-3} \mathrm{~m}$. Organic binder has been obtained from woody biomass using torrefaction process. Technological scheme has been developed which gives an opportunity to reduce the energy consumption in production line by using filtration dryers for coal and sunflower biomass drying as well as to produce bio-coal briquettes with good mechanical integrity by using organic binder along with pretreated biomass.

Key words: low quality coal, grinded sunflower biomass, bio-coal briquettes, filtration drying, composite briquettes, densification.

\section{Introduction}

Nowadays, a problem of using low quality coal is essential for Ukraine. For example, there is not sufficient economical reasonability of using reserves of low quality coal of Lviv-Volyn' coal pool in the Western region of Ukraine, which is characterized by low heating value of $8,4-10,5$ $\mathrm{MJ} / \mathrm{kg}$, high humidity, ash and sulfur content [1]. Low-quality coal dumps, with coal of 3,65-12,8 $\mathrm{MJ} / \mathrm{kg}$ heating value and high humidity, are often formed near coal mines and coal processing enterprises [2]. Briquetting is a right direction for using such coal as solid fuel. Ukraine has a large agricultural potential and the idea of utilizing the residues from agricultural sectors is considerably attractive in view of briquette production which can significantly influence the energy dependence of the country and the conservation of energy resources in general.

The production of bio-coal briquettes gives an opportunity to utilize low grade coal as well as the great amount of agricultural residues, to increase the calorific value of briquettes made by low quality coal and to improve their chemical and physical properties. The practical use of bio-coal briquettes creates new market opportunities. Furthermore, researches show that mixing coal and biomass for solid fuel production will reduce carbon emissions into the atmosphere during burning process of the briquettes [3]. Furthermore, other minor pollutants like sulfur dioxide, polyaromatic hydrocarbons (PAH), toxic organic compounds (TOC) and volatile organic compounds (VOC) can be reduced when coal and biomass are co-fired [4].

The production of composite briquettes by mixing coal and biomass in different ratios is associated with some difficulties. Briquettes strength from the composite of coal and biomass may be significantly low due to the presence of moisture content. Grinded coal and biomass should be dried before densification in view of their high moisture contents. Technological lines are often include energy ineffective drying equipment or equipment that operates in sub-optimal regimes. Belt, rotary and 


\section{Effective techniques for bio-coal briquettes production}

fluidized bed dryers are used commonly in industry for the drying processes implementation and the share of costs for drying is a significant portion in the manufacturing cost of solid fuel $[5,6]$. Since the cost of drying is a significant part of the solid fuel production cost, finding of the alternative drying methods is essential.

Various briquetting techniques have been used in the past few decades which include equipment such as pellet mills, briquette presses, screw extruders, tabletizers, and agglomerators. However, the main issues upfront in commercializing these techniques are significant binder cost and poor mechanical integrity of briquettes [9]. Woody and herbaceous biomass as well as the coal need to be preprocessed before using efficiently for fuels applications. Implementation of the filtration drying method for grinded biomass and coal gives an opportunity to intensify mass and heat transfer processes in view of good contact between the heat agent and particles of the grinded materials, to reduce drying time and energy lost through exhaust drying agent and as the result to reduce energy consumption of the drying process [7, 8]. The development of technological schemes which include torrefaction process of woody biomass is the prospective direction. Torrefaction process, which occurs at a relatively low temperature of 225-300 ${ }^{\circ} \mathrm{C}$, leads to hemicellulose and cellulose degradation as well as enacting the lignin content of biomass which makes it useful as organic binder [9-11].

\section{The aim of research}

The present study is focused on developing the technological scheme which gives an opportunity to reduce the energy consumption in production line of composite fuel as well as to produce bio-coal briquettes with good mechanical integrity.

\section{Materials and methods of research}

Coal was obtained from the Chervonograd coal factory in Ukraine. Coal as the raw material was grinded in jaw and roll crushers and screened to three fractions: $\mathrm{d}=(2,5 \div 1,25) \cdot 10^{-3} \mathrm{~m}$, $\mathrm{d}=(1,25 \div 0,63) \cdot 10^{-3} \mathrm{~m}$ and $\mathrm{d}=(0,63 \div 0,31) \cdot 10^{-3} \mathrm{~m}$. The initial moisture contents were measured for each fraction of the coal: $0,44 \mathrm{~kg} \mathrm{H}_{2} \mathrm{O} / \mathrm{kg}$ d.m. for $\mathrm{d}=(2,5 \div 1,25) \cdot 10^{-3} \mathrm{~m} ; 0,63 \mathrm{~kg} \mathrm{H}_{2} \mathrm{O} / \mathrm{kg}$ d.m. for $\mathrm{d}=(1,25 \div 0,63) \cdot 10^{-3} \mathrm{~m}$ and $0,66 \mathrm{~kg} \mathrm{H} \mathrm{H}_{2} \mathrm{O} / \mathrm{kg} \mathrm{d}$. . for $\mathrm{d}=(0,63 \div 0,31) 10^{-3} \mathrm{~m}$ (Table 1$)$.
Sunflower stems (biomass), as post-harvest residues, were obtained from a local agricultural ground in Lviv region, Ukraine. Due to their ingredients cellulose (forms wall skeleton of cells), hemicellulose (is a part of cell walls as well as the internal space of the cells) and lignin (provides walls with necessary mechanical strength and hydrophobic properties), sunflower stems can be successfully used as a raw material for solid fuel production. Stems were grinded in jaw crusher to particles from 0,08 to less than $5,0 \mathrm{~mm}$. The initial moisture content of such material was $0,67 \mathrm{~kg} \mathrm{H} \mathrm{H}_{2} \mathrm{O} / \mathrm{kg} \mathrm{d}$.m.

Apple branches (apple pruning residues), as a wooden biomass, were obtained from the pruning operations carried year by year in the apple plantations located in the Lviv region of Ukraine. Analysis showed a moisture content of 40,5\%. Apple branches were grinded to particles less than $2 \mathrm{~mm}$ for further torrefaction process of such woody biomass.

Experimental procedure for the drying process. Experiments for drying of sunflower biomass and the coal by filtration method were performed in container with the perforated bottom, as the main part of the experimental plant, in which fixed beds of the materials were formed.

An air was supplied by a blower, heated in a heater and used as the drying agent. It was filtered down flow through the fixed bed of materials. The heat agent temperature $318 \mathrm{~K}$ and the pressure drop $5886 \mathrm{~Pa}$ for the coal drying and the heat agent temperature $353 \mathrm{~K}$ and the velocity of the heat agent $1,66 \mathrm{~m} / \mathrm{s}$ were used as optimal (identified in previous studies). The constant temperatures in the inlet of the fixed bed were sustained using thermoregulatory RT-100 and chromel-copel thermocouple. Consumption of the heat agent flow was regulated by flow-regulating valves and was registered by the electronic flow-meter RPF-I. The influence of the lengths of the fixed bed on kinetic during filtration drying of coal and sunflower biomass was investigated. A set of experiments were performed for different lengths of fixed beds: for coal ranging from $\mathrm{H}=45 \cdot 10^{-3} \mathrm{~m}$ to $90 \cdot 10^{-3} \mathrm{~m}$; for sunflower stems ranging from $\mathrm{H}=30^{\cdot} \cdot 10^{-}$ ${ }^{3} \mathrm{~m}$ to $90 \cdot 10^{-3} \mathrm{~m}$. To determine the lost of weight during drying process, analytical scales were used. The experiments were carried out till the material weight became constant.

Torrefaction of woody biomass. Grinded apple branches, as woody biomass, were a subjected to torrefaction process at $250{ }^{\circ} \mathrm{C}$ and resident time of $60 \mathrm{~min}[10,11]$ in a furnace. Inert environment was 
achieved by a continuous flow of nitrogen at $21 / \mathrm{min}$ into the furnace chamber.

\section{Results and Discussions}

Drying experiments for the coal and sunflower biomass were done at laboratory plant according to the experimental procedure. The effect of the fixed bed length on the kinetic during the filtration drying were examined for the purpose of obtaining optimal values.

In view of the fact that each fraction of coal has its own initial moisture content, drying of each fraction was made separately. Experimental curves, obtained for filtration drying of coal with particle diameter $\mathrm{d}=(2,5 \div 1,25) \cdot 10^{-3} \mathrm{~m}, \mathrm{~d}=(1,25 \div 0,63) \cdot 10^{-3} \mathrm{~m}$ and $\mathrm{d}=(0,63 \div 0,31) \cdot 10^{-3} \mathrm{~m}$ are presented in Fig. $1-3$.

w, $\mathrm{kg} \mathrm{H}_{2} \mathrm{O} / \mathrm{kg} \mathrm{d.m}$

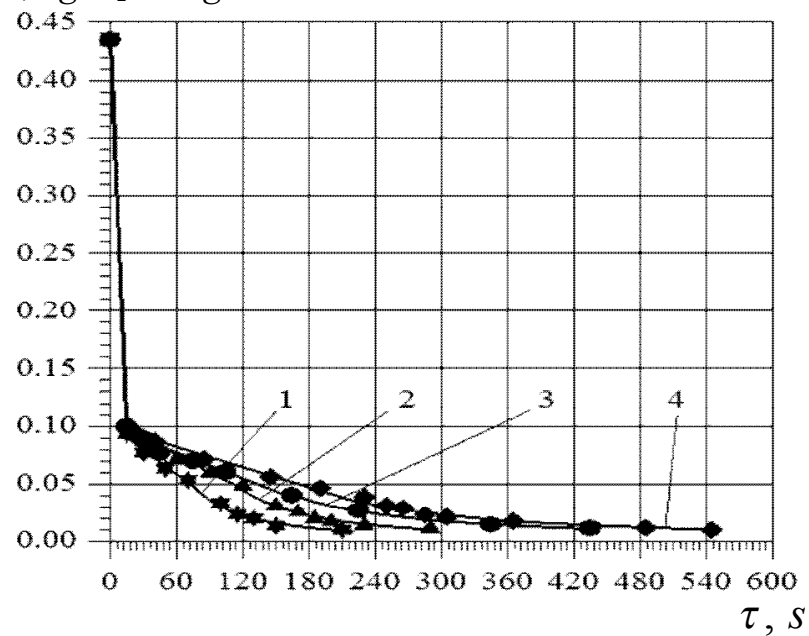

Fig. 1. Kinetic of the filtration drying of coal $d=(2,5 \div 1,25) \cdot 10^{-3} \mathrm{~m}$ at different lengths of the fixed bed: $1-H=45 \cdot 10^{-3} \mathrm{~m} ; 2-H=60 \cdot 10^{-3} \mathrm{~m} ; 3-H=75 \cdot 10^{-3} \mathrm{~m} ; 4-$ $H=90 \cdot 10^{-3} \mathrm{~m} .(T=318 \mathrm{~K}, \Delta P=5886 \mathrm{~Pa})$

w, $\mathrm{kg} \mathrm{H}_{2} \mathrm{O} / \mathrm{kgd} . \mathrm{m}$

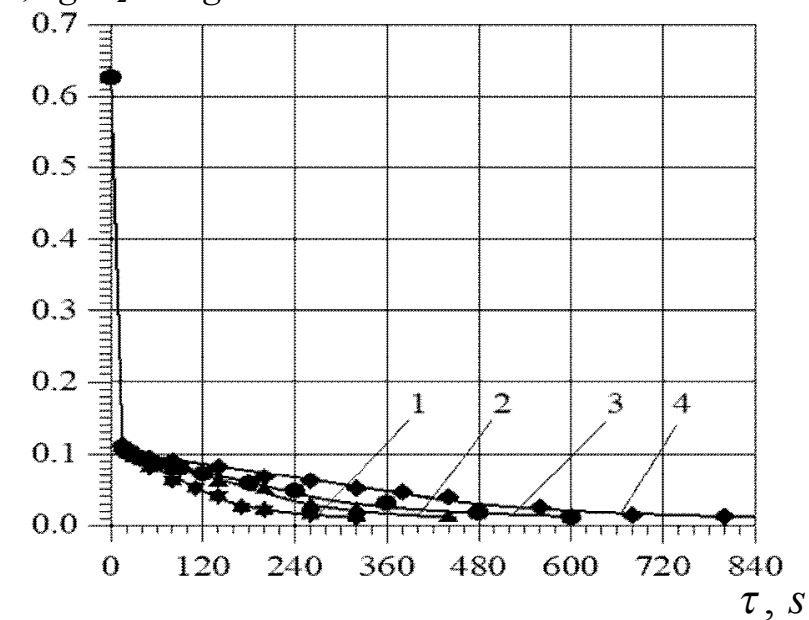

Fig. 2. Kinetic of the filtration drying of coal $d=(1,25 \div 0,63) \cdot 10^{-3} \mathrm{~m}$ at different lengths of the fixed bed: $1-H=45 \cdot 10^{-3} \mathrm{~m} ; 2-H=60 \cdot 10^{-3} \mathrm{~m} ; 3-H=75 \cdot 10^{-3} \mathrm{~m} ; 4-$ $H=90 \cdot 10^{-3} \mathrm{~m} .(T=318 \mathrm{~K}, \Delta P=5886 \mathrm{~Pa})$ w, $\mathrm{kg} \mathrm{H}_{2} \mathrm{O} / \mathrm{kg} \mathrm{d.m}$

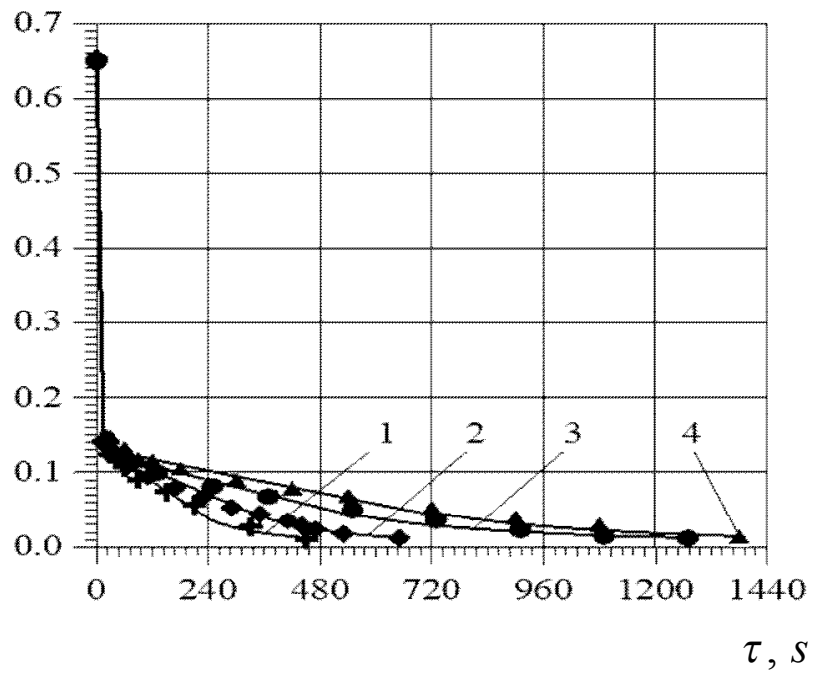

Fig. 3. Kinetic of the filtration drying of coal $d=(0,63 \div 0,31) \cdot 10^{-3} \mathrm{~m}$ at different lengths of the fixed bed: $1-H=45 \cdot 10^{-3} \mathrm{~m} ; 2-H=60 \cdot 10^{-3} \mathrm{~m} ; 3-H=75 \cdot 10^{-3} \mathrm{~m} ; 4-$ $H=90 \cdot 10^{-3} \mathrm{~m} .(T=318 \mathrm{~K}, \Delta P=5886 \mathrm{~Pa})$

As it is seen from the graphs, kinetic curves for all coal fractions have (Fig. 1-3) periods of mechanical displacement and removal of moisture from the material and periods of complete and partial saturation of the heat agent by moisture. Surface moisture is located in channels between the coal particles and the reduction of the particles size leads to the increasing of its amount in the layer of the material. In view of the low binding energy of the surface moisture with the material, it is easily removed from the material by the moving heat agent in a few seconds in the periods of mechanical displacement and removal of moisture, which saves energy coasts on the implementation of the drying process.

Drying times for all fractions of coal at lengths of the fixed bed $45 \cdot 10^{-3} \mathrm{~m} ; 60 \cdot 10^{-3} \mathrm{~m} ; 75 \cdot 10^{-3}$ mand $90 \cdot 10^{-3} \mathrm{~m}$ are given at Table 1 . As the result of the energy costs calculation, length of the fixed bed $75 \cdot 10^{-3} \mathrm{~m}$ was obtained as optimal for realization of the coal drying by filtration method.

Experimental results of the drying process for grinded sunflower biomass are represented in Fig. 4. The kinetic curves (Fig. 4) are characterized by periods of complete and partial saturation of the heat agent by moisture. Long period of partial saturation of the heat agent by moisture indicates the proceeding of pore-diffusion processes in the material particles which define the time of filtration drying. 
Effective techniques for bio-coal briquettes production

Table

Drying times for all fractions of coal at different lengths of the fixed bed

\begin{tabular}{|c|c|c|c|c|c|}
\hline \multirow{2}{*}{$\begin{array}{c}\text { Fraction size, } \\
\quad \mathrm{d} \cdot 10^{-3} \mathrm{~m}\end{array}$} & \multirow{2}{*}{$\begin{array}{c}\text { Initial moisture } \\
\text { content, } \\
\text { w, } \mathrm{kg} \mathrm{H}_{2} \mathrm{O} / \mathrm{kg} \text { d.m. }\end{array}$} & \multicolumn{4}{|c|}{ Drying time, $\tau, \mathrm{s}$} \\
\hline & & $\left(\mathrm{H}=45 \cdot 10^{-3} \mathrm{~m}\right)$ & $\left(\mathrm{H}=60 \cdot 10^{-3} \mathrm{~m}\right)$ & $\left(\mathrm{H}=75 \cdot 10^{-3} \mathrm{~m}\right)$ & $\left(\mathrm{H}=90 \cdot 10^{-3} \mathrm{~m}\right)$ \\
\hline $2,5 \div 1,25$ & 0,44 & 210 & 288 & 440 & 546 \\
\hline $1,25 \div 0,63$ & 0,63 & 320 & 440 & 615 & 820 \\
\hline $0,63 \div 0,31$ & 0,66 & 456 & 646 & 1275 & 1399 \\
\hline
\end{tabular}

w, $\mathrm{kg} \mathrm{H} \mathrm{H}_{2} \mathrm{O} / \mathrm{kg} \mathrm{d} . \mathrm{m}$

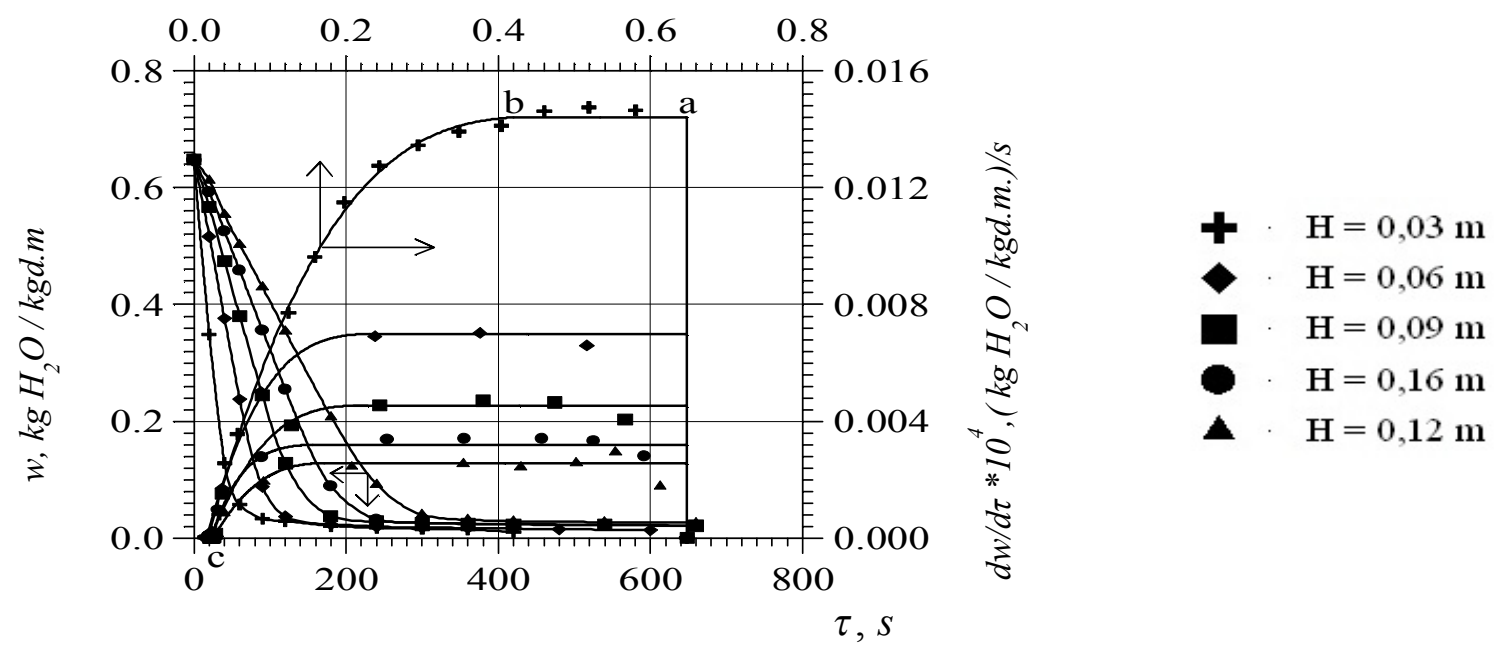

Fig. 4. Kinetic of the filtration drying of sunflower biomass. at different lengths of the fixed bed $(T=353 \mathrm{~K} ; \quad=1,66 \mathrm{~m} / \mathrm{s})$

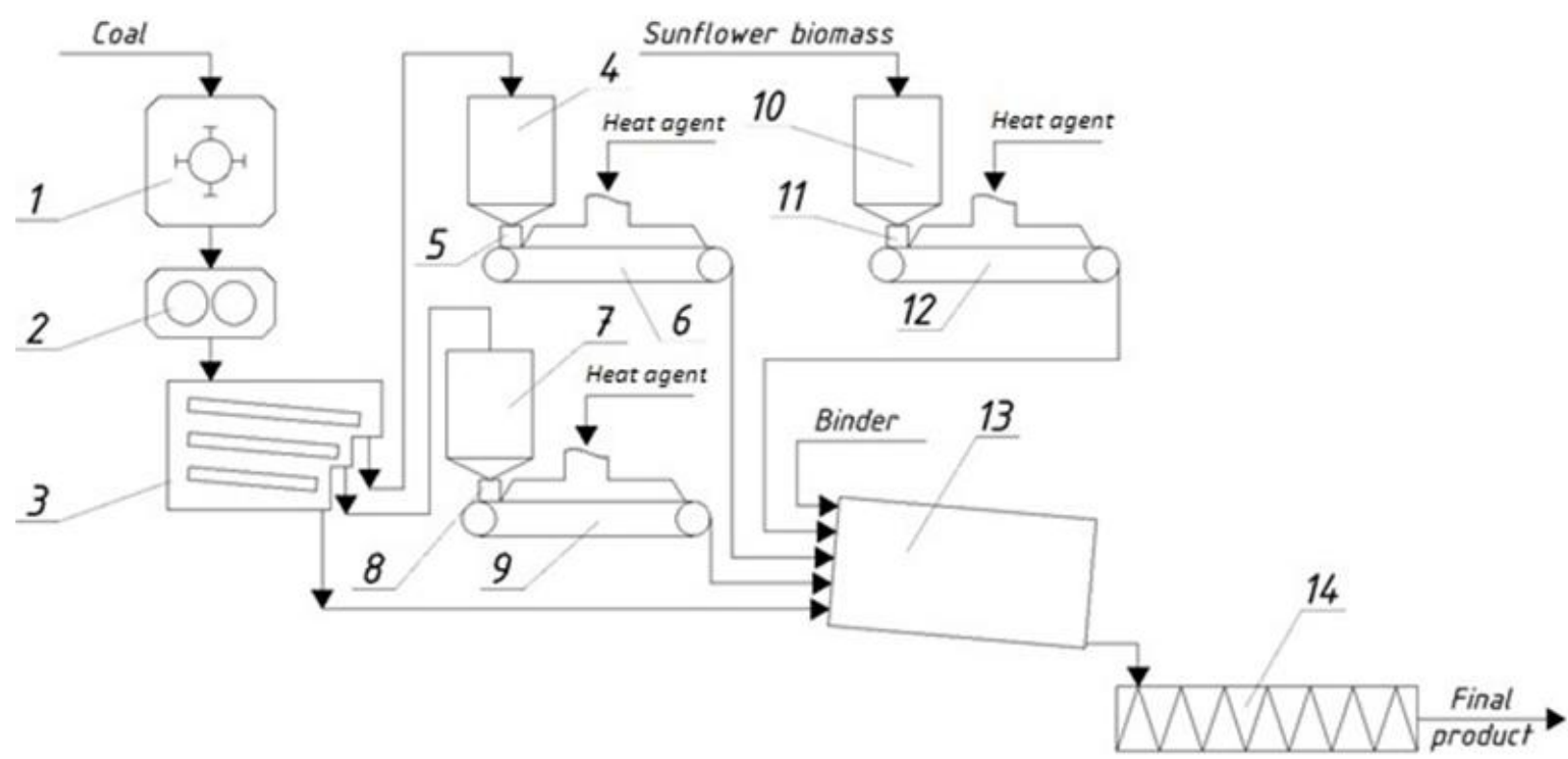

Fig. 5. The technological scheme for bio-coal briquettes production: 1 -jaw crusher; 2 -roll crusher; 3 -crashes; 4, 7, 10-containers; 5, 8, 11 -dispensers; 6, 9, 12 -filtration dryers; 13 -mixer; 14 -crew press 


\section{P. Kindzera, R. R. Hosovskyi, Z. Ya. Hnativ, V. M. Atamanyuk}

As the result of the energy costs calculation, length of the fixed bed $120 \cdot 10^{-3} \mathrm{~m}$ was obtained as optimal for realization of the sunflower biomass drying by filtration method.

Technological scheme (Fig. 5) was developed for bio-coal briquettes production taking into account recommendations $[12,13]$. It gives an opportunity to reduce the energy consumption in production line by using filtration dryers as well as to produce bio-coal briquettes with good mechanical integrity by using organic binder along with pretreated biomass.

According to the technological scheme, the coal is grinded in the jaw crusher (1) and the roll crusher (2) and screened to three fractions with the help of crashes (3). Bigger fractions after crashes (3) are fed into containers (4 and 7). With the help of dispensers $(5,8)$ coal fractions are fed to filtration dryers $(6,9)$ and then to the mixer (13). The smallest fraction is fed directly to the mixer (13) due to its small amount and considerable hydraulic resistance during filtration drying. Grinded sunflower biomass from container (10) with the help of dispenser (11) is fed to filtration dryer (12). Dried sunflower biomass is fed to the mixer (13). In mixer (13) coal, sunflower biomass and binder (obtained after the torrefaction of woody biomass) are homogeneously mixed. For production of bio-coal briquettes crew press (14) is used.

\section{Conclusions}

The influence of lengths of the fixed bed on kinetics during the filtration drying of grinded coal and sunflower biomass was investigated and optimal parameters for the process implementation were identified for sunflower biomass: temperature of the heat agent $353 \mathrm{~K}$, velocity of the heat agent $1,66 \mathrm{~m} / \mathrm{s}$, length of the fixed bed $120 \cdot 10^{-3} \mathrm{~m}$ and for the coal: temperature of the heat agent $318 \mathrm{~K}$; pressure drop $5886 \mathrm{~Pa}$, length of the fixed bed $75 \cdot 10^{-3} \mathrm{~m}$. Filtration drying of grinded sunflower biomass and coal as the unit operation of the technological line for bio-coal briquettes production has been proposed.

\section{References}

1. Heletii Z., Roskolupa A., Mysak Y. and Kravets T. (2002). Ekonomichna efektyvnist vykorystannia nyzkoiakisnoho tverdoho palyva zakhidnoho rehionu Ukrainy dlia vyrobnytstva elektroenerhii. Visnyk $N U$ "Lvivska Politekhnika", 460, 123-127.

2. Protsyshyn B., Vorobiov L., Lokh Y. and Pavliuk S. (2006). Vyrobnytstvo kompozytsiinykh palyv z vidkhodiv promyslovosti ta silskoho hospodarstva. Prom. teplotekhnyka, 28(2), 46-50.

3. Ikelle, I. and Oga, S. (2014). Determination of Heating Ability of Coal and Corn Cob Briquettes. IOSR Journal of Applied Chemistry (IOSR-JAC), 7(2), 77-82.

4. Jones J., Kubacki M., Kubica K., Ross A.B., Williams A. (2005), "Devolatilisation Characteristics of Coal and Biomass Blends", Journal of Analytical and Applied Pyrolysis, 74, 502-511.

5. Snezhkin, Y., Korinchuk, D., Vorobiov, L. and Kharin, O. (2006). Rozrobka enerhoefektyvnoho palyva na torfianii osnovi. Prom. Teplotechn, 28, 41-45.

6. Kindzera D., Atamanyuk V., Pelekh M., Hosovskyi R. (2019). Chemistry, Technology and Application of Substances, 2(1), 110-114.

7. Kindzera D., Atamanyuk V. and Hosovskyi R. (2015). Vyznachennia optymalnykh parametriv sushinnia podribnenykh stebel soniashnyka dlia vyrobnytstva palyvnykh bryketiv. Visnyk Odesa Nats. Acad, 42, 194 198.

8. Kindzera D., Hosovkyi R., Atamanyuk V. (2019). Intensyfikatsiia vnutrishnodyfuziinoho masoperenesennia ta nasychennia teplovoho ahentu volohoiu dlia pidvyshchennia enerhoefektyvnosti sushinnia roslynnoi biomasy. Visnyk Odesa Nats. Acad, 1(83), 103-110.

9. Adeleke A., Odusote J., Lasode O., Ikubanni P., Malathi M., Paswan D. (2019). Densification of coal fines and mildly torrefied biomass into composite fuel using different organic binders. Heliyon, 5, 1-7.

10. Adeleke A., Odusote J., Lasode O., Ikubanni P., Malathi M., Paswan D. (2019). Mild pyrolytic treatment of gmelina arborea for optimum energetic yields. Cogent Eng., 6(1), 1-13.

11. Odusote J., Adeleke A., Lasode O., Malathi M., Paswan D. (2019). Thermal and compositional properties of treated Tectona grandis. Biomass conversion and biorefinery, 3, 511-519.

12. Krizan, P., Soos, L. and Vukelic, D. (2009). A Study of Impact Technological Parameters on the Briquetting Process. Facta Universitatis ser.: Working Living Environ, 6, 39-47.

13. Chaiklangmuang S., Supa $S$ and Kaewpet $P$. (2008). Development of Fuel Briquettes from BiomassLignite Blends. Chiang Mai J. Sci., 35(1), 43-50. 


\section{Effective techniques for bio-coal briquettes production}

Д. П. Кіндзера, Р. Р. Госовський, В. М. Атаманюк, 3. Я. Гнатів

${ }^{1}$ Національний університет “Львівська політехніка",

кафедра хімічної інженерії

kindzera74@ukr.net

\section{ЕФЕКТИВНІ МЕТОДИ ВИРОБНИЦТВА БІО-ВУГІЛЬНИХ БРИКЕТІВ}

Виробництво біо-вугільних брикетів дає змогу утилізувати низькосортне вугілля та значну кількість сільськогосподарських залишків, підвищити теплотворну здатність брикетів та поліпшити їх хімічні та фізичні характеристики. Дослідження спрямовані на розроблення технологічної схеми, яка дає змогу зменшити енергетичні затрати виробничих ліній композиційного палива та виробляти біо-вугільні брикети належної міцності. Досліджено вплив висоти стаціонарного шару на кінетику фільтраційного сушіння вугілля та біомаси соняшника. Оптимальні параметри для проведення процесу визначено для біомаси соняшника: температура теплового агента 353 К; швидкість теплового агента $1,66 \mathrm{~m} / \mathrm{c}$; висота стаціонарного шару $12010^{-3}$ м та для вугілля: температура теплового агента 318 К; перепад тисків 5886 Па; висота стаціонарного шару $7510^{-3}$ м. Органічну зв'язуючу речовину отримано обпалюванням деревинної біомаси. Розроблено технологічну схему, яка дає змогу зменшити енергетичні затрати виробничих ліній використанням фільтраційних сушарок для сушіння вугілля та біомаси соняшника та виробляти біо-вугільні брикети належної міцності, змішуючи органічну зв'язуючу речовину з біомасою, що пройшла попередню переробку.

Ключові слова: низькосортне вугілля, подрібнена біомаса соняшника, біо-вугільні брикети, фільтраційне сушіння, композиційні брикети, ущільнення. 